\title{
Proteomics analysis of A375 human malignant melanoma cells in response to arbutin treatment
}

\author{
Jiraporn Nawarak a , Rosa Huang-Liu ${ }^{\mathrm{b}}$, Shao-Hsuan Kao ${ }^{\mathrm{c}}$, Hsien-Hua Liao ${ }^{\mathrm{d}}$, Supachok Sinchaikul ${ }^{\mathrm{a}}$, \\ Shui-Tein Chen ${ }^{\mathrm{a}, \mathrm{e}}$, Sun-Long Cheng ${ }^{\mathrm{d}, *}$ \\ a Institute of Biological Chemistry and Genomics Research Center, Academia Sinica, Taipei 11529, Taiwan \\ b School of Nutrition, Chung Shan Medical University, Taichung 40242, Taiwan \\ ' Institute of Biochemistry and Biotechnology, Chung Shan Medical University, Taichung 40242, Taiwan \\ d Department of Plastic Surgery, Chung Shan Medical University, Chung Shan Medical University Hospital, Taichung 40242, Taiwan \\ e Institute of Biochemical Sciences, College of Life Science, National Taiwan University, Taipei 10617, Taiwan
}

\section{A R T I C L E I N F O}

\section{Article history:}

Received 3 April 2008

Received in revised form 12 September 2008

Accepted 29 September 2008

Available online 18 October 2008

\section{Keywords:}

Arbutin

A375 cells

Malignant melanoma

Proteomics

Cancer

\begin{abstract}
A B S T R A C T
Although the toxicogenomics of A375 human malignant melanoma cells treated with arbutin have been elucidated using DNA microarray, the proteomics of the cellular response to this compound are still poorly understood. In this study, we performed proteomic analyses to investigate the anticancer effect of arbutin on the protein expression profile in A375 cells. After treatment with arbutin $(8 \mu \mathrm{g} / \mathrm{ml})$ for 24,48 and $72 \mathrm{~h}$, the proteomic profiles of control and arbutin-treated A375 cells were compared, and 26 differentially expressed proteins ( 7 upregulated and 19 downregulated proteins) were identified by MALDI-Q-TOF MS and MS/MS. Among these proteins, 13 isoforms of six identical proteins were observed. Bioinformatic tools were used to search for protein function and to predict protein interactions. The interaction network of 14 differentially expressed proteins was found to be correlated with the downstream regulation of p53 tumor suppressor and cell apoptosis. In addition, three upregulated proteins (14-3-3G, VDAC-1 and p53) and five downregulated proteins (ENPL, ENOA, IMDH2, PRDX1 and VIME) in arbutin-treated A375 cells were validated by RT-PCR analysis. These proteins were found to play important roles in the suppression of cancer development.
\end{abstract}

(c) 2008 Elsevier B.V. All rights reserved.

\section{Introduction}

Standard topical treatments for hyperpigmentation disorders, such as melasma and post-inflammatory hyperpigmentation, and for some dermatological disorders include hydroquinones, retinoids and tyrosinase inhibitors. Tyrosinase inhibitors are becoming increasingly important in the cosmetics and medicinal industries due to their preventive effects on pigmentation disorders. A number of tyrosinase inhibitors have been reported from both natural and synthetic sources, but only a few of these are used as skin-whitening agents, primarily due to various safety concerns. Among the skin-whitening agents, arbutin (hydroquinone-O- $\beta$-D-glucopyranoside) is a glycosylated hydroquinone found at high concentrations in certain plants and is widely used as an ingredient in skin care products [1]. Arbutin is effective in the topical treatment of various cutaneous hyperpigmentations. The depigmenting mechanism of arbutin in humans involves the inhibition of melanosomal tyrosinase activity, rather than the suppression of the expression or synthesis of the enzyme [2-5].

\footnotetext{
* Corresponding author. Tel.: +886 424719933.

E-mail address: chuangs1@ms57.hinet.net (S.-L. Cheng).
}

Arbutin concentrations in the range of $0.5-8 \mathrm{mM}$ increase the pigmentation of the cultured melanocytes [6]. Arbutin has not been reported to induce gene mutations in the absence of an activating system, although it is strongly mutagenic in the presence of cytosolic fractions from human intestinal bacteria E. ramulus and B. distasonis [7]. In our previous study, the effect of arbutin on gene expression in human malignant melanoma cells was investigated using microarray. The microarray results indicated that, at safe levels, arbutin can induce a change in gene expression. There were 324 significantly differentially expressed genes ( 88 upregulated genes and 236 downregulated genes). The correlation of differentially expressed genes with signaling pathways of malignant melanogenesis and tumorigenesis was built by combining the databases of pathways. The significant arbutinresponsive genes, AKT1, FGFR3 and LRP6, are correlated with the AKT, RAS, MAPK and WNT signaling pathways [8]. In addition to having a relationship with the tyrosinase enzyme, their biological activities are also associated with cell proliferation, differentiation and apoptosis $[9,10]$. These genes play key roles in the regulation of malignant melanogenesis of arbutin-treated A375 cells.

From the microarray results, it was suggested that arbutin has a potential role as an antitumor agent. Although the effects of arbutin on gene expression had previously been determined by microarray, the 
biological effects, functional mechanism, and tumorigenic potential on protein expression levels of malignant tumorigenesis have never been reported. In this study, we used 2-D PAGE to investigate the biological effects of arbutin on the protein expression profile of A375 human malignant melanoma cells and on the melanocytic tumorigenesis and other related side effects of cancer therapy. In addition, we used the bioinformatics tools for searching protein ontology, classification and cellular response in order to gain a better understanding of the regulatory mechanism of arbutin on the protein expression levels of human skin cancer cells.

\section{Materials and methods}

\subsection{Test substances and chemicals}

The human malignant melanoma cell line A375 (CRL-1619) was obtained from ATCC (Rockville, MD, USA.). Fetal bovine serum (FBS), sodium pyruvate, antibiotic-antimycotic and TRIzol reagent were purchased from Invitrogen (Carlsbad, CA, USA). Dulbecco's Modified Eagle's Medium (DMEM) and Trypsin-EDTA were purchased from Atlanta Biologicals (Norcross, GA, USA). Arbutin and sodium bicarbonate were purchased from Sigma (St. Louis, MO, USA). IPGphor, immobiline drystrips and carrier ampholytes were purchased from GE Healthcare (Uppsala, Sweden). Urea and CHAPS were purchased from J.T. Baker (Phillipsburg, NJ, USA). Iodoacetamide was purchased from Fluka (Buchs, Switzerland). Dithioerythritol (DTE) was purchased from AppliChem (Darmstadt, Germany). Sypro ${ }^{\circledR}$ Ruby was purchased from Molecular Probes (Eugene, OR, USA). Deionized water was prepared with a tandem Milli-Q system (Millipore, Bedford, MA, USA) and used for the preparation of all buffers.

\subsection{Cell culture and treatment}

A375 human malignant melanoma cells were cultured in DMEM medium supplemented with $10 \% \mathrm{FBS}, 1.5 \mathrm{~g} / \mathrm{ml}$ sodium bicarbonate, $1 \mathrm{mM}$ sodium pyruvate and $1 \%$ antibiotic-antimycotic in a humidified incubator with $5 \% \mathrm{CO}_{2}$ at $37{ }^{\circ} \mathrm{C}$. During subculture, the medium was replaced every 2 days. To perform cell attachment, A375 cells were seeded at $1.5 \times 10^{6}$ cell $/ \mathrm{ml}$ in a $110 \mathrm{~mm}$ Petri dish cell culture plate (NUNC ${ }^{\mathrm{TM}}$, Roskilde, Denmark) in $9.0 \mathrm{ml}$ of culture media overnight. The cells were then cultured either alone or in the presence of arbutin at a concentration of $8 \mu \mathrm{g} / \mathrm{ml}$ for 24,48 and $72 \mathrm{~h}$. The cells were harvested by treatment with trypsin-EDTA, washed two times with sterile PBS and stored at $4{ }^{\circ} \mathrm{C}$ until further use.

\subsection{Two-dimensional electrophoresis (2-D PAGE)}

A375 cells were resuspended in $350 \mu$ of a lysis buffer containing 7 M Urea, 4\% CHAPS, 2 M Thiourea, 65 mM DTE and 0.5\% IPG buffer $\mathrm{pH}$ 3-10NL. For the first dimensional isoelectric focusing (IEF), the protein solutions $(150 \mu \mathrm{g})$ were applied onto IPG strips (18 cm, pH 3-10NL). Rehydration was performed with an IPGphor IEF system (GE Healthcare) at $20{ }^{\circ} \mathrm{C}$ and $30 \mathrm{~V}$ for $12 \mathrm{~h}$. Subsequently, IEF was conducted at $8000 \mathrm{~V}$ for $70 \mathrm{kVh}$. After IEF, the IPG strips were equilibrated with equilibration buffer ( $50 \mathrm{mM}$ Tris- $\mathrm{HCl} \mathrm{pH} 8.8,6 \mathrm{M}$ urea, $2 \%$ SDS, $30 \%$ glycerol, $2 \%$ DTE and a trace of bromophenol blue) for $15 \mathrm{~min}$ and then in another similar buffer, where DTE was replaced with $2.5 \%$ iodoacetamide (IAA), for a further $15 \mathrm{~min}$. The IPG strips were transferred onto a $12.5 \%$ homogeneous polyacrylamide gel $(18 \times 18 \mathrm{~cm})$, and the second dimensional separation was performed in a Protean II xi Cell at $45 \mathrm{~mA}$ per gel at $8^{\circ} \mathrm{C}$ until the bromophenol blue dye front reached the bottom of the gel. Proteins were visualized with Sypro ${ }^{\circledR}$ Ruby dye. The 2-D gel images were scanned using a Typhoon laser scanner (GE Healthcare, Uppsala, Sweden) and exported to the image analysis software program using PDQuest package software version 7.1.1 (Bio-Rad, Hercules, CA, USA).

\subsection{In-gel tryptic digestion}

Differentially expressed spots were manually excised from the gels and transferred to $500 \mu \mathrm{l}$ siliconized eppendorf tubes. The gel pieces were washed twice with $200 \mu \mathrm{l}$ of $50 \% \mathrm{ACN} / 25 \mathrm{mM}$ ammonium bicarbonate buffer, $\mathrm{pH} 8.0$, for $15 \mathrm{~min}$ each. The gel pieces were then washed once with $200 \mu \mathrm{l}$ of $100 \%$ ACN and dried in a SpeedVac concentrator. Dried gel pieces were swollen in $20 \mu \mathrm{l}$ of $25 \mathrm{mM}$ ammonium bicarbonate containing $5 \mathrm{ng}$ of sequencing grade modified trypsin (Promega, Madison, WI). Gel pieces were incubated at $37{ }^{\circ} \mathrm{C}$ for at least $16 \mathrm{~h}$. Peptides were subsequently extracted three times with $50 \mu \mathrm{l}$ of $50 \% \mathrm{ACN} / 1 \% \mathrm{TFA}$, and then the extracted solutions were combined and dried in a SpeedVac concentrator. The peptide pellets were resuspended in $4 \mu \mathrm{l}$ of $20 \%$ ACN/0.1\% TFA for MS analysis.

\subsection{MALDI-TOF MS and MS/MS analysis}

The trypsinized samples were premixed in a $1: 1$ ratio with the matrix solution, containing $5 \mathrm{mg} / \mathrm{ml} \alpha$-cyano-4-hydroxy-cinnamic acid (CHCA) in 50\% ACN, 0.1\% v/v TFA and $2 \% \mathrm{w} / \mathrm{v}$ ammonium citrate, and spotted onto the 96-well MALDI target plate. The samples were analyzed by the Q-TOF Ultima ${ }^{\mathrm{TM}}$ MALDI instrument (M@LDI ${ }^{\mathrm{TM}}$; Micromass, Manchester, UK), which was fully automated with a predefined probe motion pattern and peak intensity threshold for switching over from MS survey scanning to MS/MS and from one MS/ MS to another. Within each sample well, parent ions that met the predefined criteria (any peak within the $\mathrm{m} / \mathrm{z}$ 800-3000 range with an intensity above 10 count \pm include/exclude list) were selected for CID MS/MS using argon as the collision gas and a mass dependent $\pm 5 \mathrm{~V}$ rolling collision energy until the end of the probe pattern was reached. The MS and MS/MS ion data were extracted and output as searchable .txt and .pkl files, respectively, for independent searches using the MASCOT search engine (http://www.matrixscience.com), assuming that peptides were monoisotopic, oxidized at methionine residues and carbamidomethylated at cysteine residues. Only one missed trypsin cleavage was allowed, and peptide mass tolerances of $50 \mathrm{ppm}$ were used for PMF and MS/MS ions search. The search was performed using the Swiss-Prot human protein database.

\section{6. $R T-P C R$}

After A375 cells treated with arbutin at 24, 48 and 72 h were collected, total RNA was extracted by a modified method using TRIzol reagent combined with RNeasy Mini Kit (Qiagen, Hilden, Germany), according to the manufacturer's instructions. The total RNA was quantified by a NanoDrop ${ }^{\circledR}$ ND-1000 UV-Vis Spectrophotometer (Thermo Fisher Scientific, Wilmington, DE, USA). A mixture of oligo dT, DTT, dNTP, reaction buffer and reverse transcriptase was added to RNA samples. RNA was then converted to cDNA by incubating at $42^{\circ} \mathrm{C}$ for $50 \mathrm{~min}$. The cDNA were stored at $-20{ }^{\circ} \mathrm{C}$ until further use. The sequences of primers used were: (1) 14-3-3G: forward 5'-CGAGCAACTGGTGCAGAAA-3' and reverse 5'-TTCTCATTGCCGTCTGCAGAT-3'; (2) VDAC-1: forward 5'-AGGAATGACGGGACAG AGTTT-3' and reverse 5'AGATACCCACCGAGAAGCAG-3'; (3) PRDX1: forward 5'-TGGTGTCGGTGGTTAGTTTCT-3' and reverse 5'-TGCCCTATCACTGAAAGCAA-3'; (4) ENPL: 5'-ATGGAGATCCTGGAATAGGCA-3' and reverse 5'-GCTTTTCTCCAATCAAATGGC-3'; (5) IMDH2: forward 5'-CAACACTCATGCCAGGACATT-3' and reverse 5'-TATGGACGCCACCTTCCAC-3'; (6) ENOA: forward $5^{\prime}$-TTTTCTCGCCTCACTTTCCA-3' and reverse $5^{\prime}$ ATGGGTCACTGAGGCTTTTT-3'; (7) p53: forward 5'-TGAATGAGGC CTTGGAATTAAAG-3' and reverse 5'-TGGAGTGAGCCCTGCTGTCT-3'; (8) VIME: forward 5'-TCTGGTTGATACCCACTCAAA-3' and reverse 5'AGGCACTTGAAAGCTGTTTCT-3'. PCR was carried out with a Px2 Thermal Cycler (Thermo Fisher Scientific, CA, USA). The PCR reaction began with heating at $94{ }^{\circ} \mathrm{C}$ for $5 \mathrm{~min}$, followed by 25 cycles of 
denaturation at $94{ }^{\circ} \mathrm{C}$ for $1 \mathrm{~min}$, annealing at $52-55{ }^{\circ} \mathrm{C}$ for $45 \mathrm{~s}$, extension at $72{ }^{\circ} \mathrm{C}$ for $1 \mathrm{~min}$, and concluded with an incubation step at $72{ }^{\circ} \mathrm{C}$ for $7 \mathrm{~min}$. The PCR products were analyzed on $1.5 \%$ agarose gels. The agarose gels were stained with ethidium bromide and photographed under UV illumination. The RT-PCR of the encoded genes of differentially expressed proteins was performed in triplicate. ImageMaster software was used to detect the band intensity of all PCR products. The fold expression of the target gene relative to $\beta$-actin was calculated for each sample by the formula: expression ratio $=\Delta$ sample $\Delta$ control; $\Delta$ sample $=$ average band intensity of arbutin-treated sampleaverage band intensity of $\beta$-actin; $\Delta$ control=average band intensity of control-average band intensity of $\beta$-actin.

\subsection{Statistical analysis}

Three triplicate experiments were done for the cell treatment and subsequent 2-D PAGE analysis of the control and arbutin-treated (24, 48 and 72 h) cells. Each group of 2-D gel images was statistically analyzed by image analysis software separately, and the change in protein expression or regulation was determined by dividing the mean spot density of a spot of interest from the arbutin-treated group divided by the mean spot density for the same spot from the control group. Data are expressed as mean value and standard derivation (SD). Differentially expressed protein spots that were found in all sets of experiments were selected for protein identification.

\subsection{Bioinformatics tools for protein searches}

To search protein ontology, we used a combination of databases to gain information on protein annotation, subcellular location, family and superfamily classification, similar proteins, proteins encoding genes, molecular function, biochemically functionally related proteins, and references. Protein searches followed this sequential order of databases: NCBI (http://www.ncbi.nlm.nih.gov), Swiss-Prot/TrEMBL (http://www.expasy.ch/sprot) and Proteome (http://www.proteom. com/databases/HumanPD/reports). In addition, the functional protein association networks or protein interactions were searched by the STRING database (http://string.embl.de/). The combination of pathway databases of BioCarta (http://www.biocarta.com) and KEGG (http://www.genome.ad.jp/kegg/pathways.html) with the NCBI (PubMed) literature (http://www.ncbi.nlm.nih.gov/PubMed) was also used to search the correlated regulatory pathways of cellular responses in A375 cells. Protein-protein interaction scores were obtained from the STRING database.

\section{Results}

\subsection{2-D PAGE of A375 cells in response to arbutin treatment}

The 2-D gel images of A375 cells without treatment (control) and with arbutin treatment at 24, 48 and 72 h are shown in Fig. 1. Most of
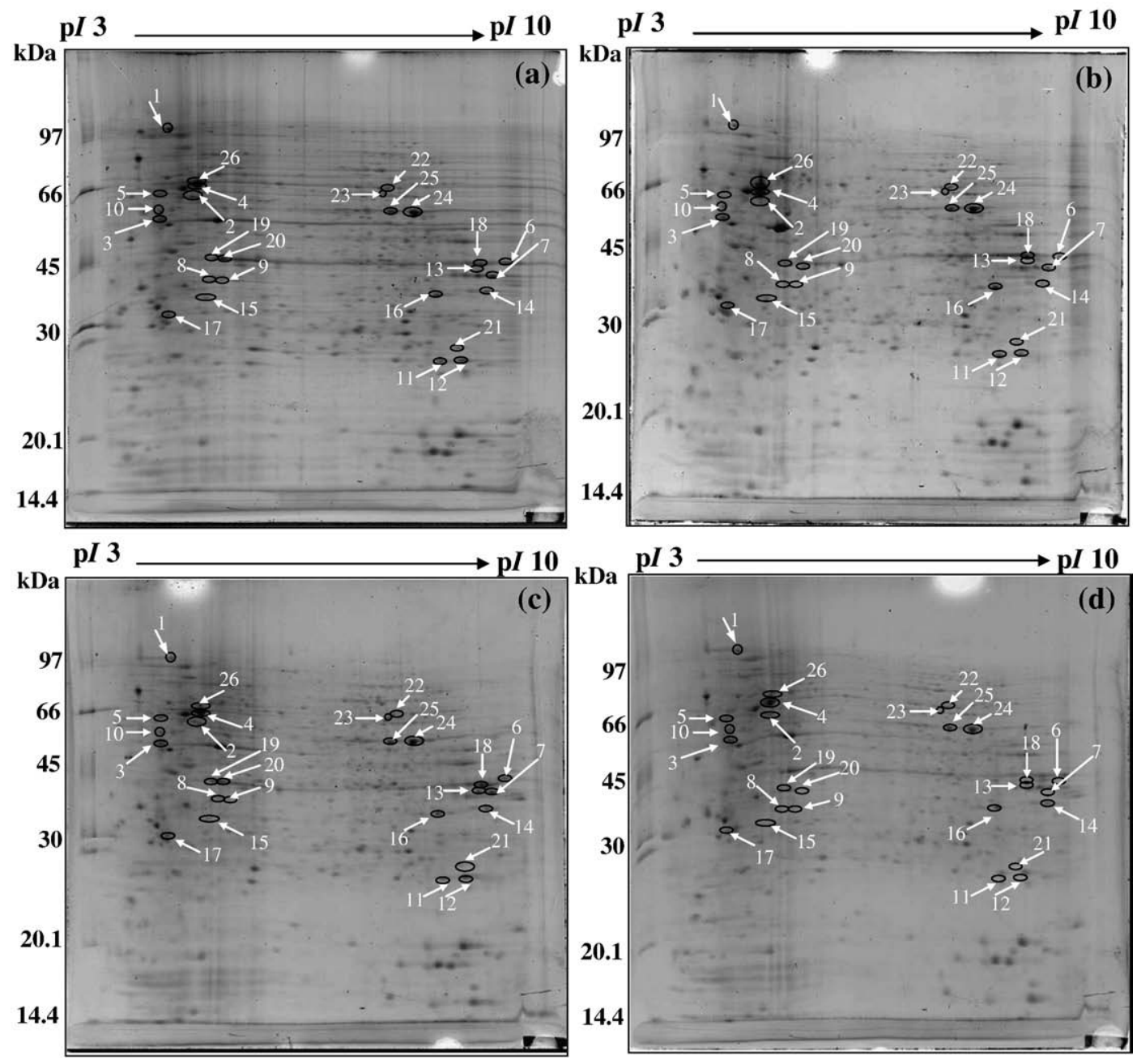

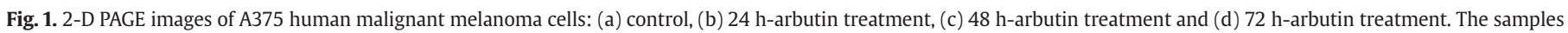
were separated on a homogeneous 12.5\% SDS-PAGE gel using an IPG strip pH 3-10 NL. The pointed arrows indicate the identified protein spots in this study. 
the proteins were distributed within the molecular weight range from 25 to $97 \mathrm{kDa}$, and the differentially expressed protein spots were distributed between acidic and basic regions. Using PDQuest image analysis software, the total number of protein spots from the control and treatment groups was about 540 spots with no significant difference among the groups. Among these protein spots, there were 40 differentially expressed protein spots, containing 10 upregulated protein spots, in which the threshold of change in expression level was 1.0 fold, and 40 downregulated protein spots, in which the threshold of change in expression level was 0.9 fold.

\subsection{Protein identification of differentially expressed proteins}

Using the MASCOT protein identification search software for identifying both PMF and MS/MS ion mass data, 26 differentially expressed proteins were successfully identified. A list of identified proteins, Mowse score, apparent and theoretical MW and $\mathrm{pI}$, number of PMF and MS/MS matched sequences, coverage, regulation or change in expression level and standard deviation value are shown in Table 1. The PMF and MS/MS matched peptide sequences of 26 identified proteins are also shown in Table S1. Among these proteins, there were five upregulated and 15 downregulated proteins (including their isoforms).
Most of the identified proteins were downregulated in arbutin-treated A375 cells and 13 isoforms of six identical proteins were observed. There were two vimentins, two heterogeneous nuclear ribonucleoproteins A2/B1, two heterogeneous nuclear ribonucleoproteins A1, two peroxiredoxins-1, three glyceraldehyde-3-phosphate dehydrogenases and two alpha-enolases, which account for about $50 \%$ of all of the identified proteins and might be caused by post-translational modifications.

The differentially expressed proteins in arbutin-treated A375 cells are classified according to cellular component, molecular function and biological process and their protein interaction partners are predicted in Table 2. The identified proteins were distributed to many locations in the cellular component, have diverse functions, and were found to play important roles in many biological processes, especially in cancer biology, such as in apoptosis, regulation of angiogenesis, regulation of cell proliferation, regulation of cell differentiation and the immune response. Interestingly, five identified proteins, heat shock protein $90 \mathrm{kDa}$ beta member 1 (ENPL), voltage-dependent anion-selective channel protein 1 (VDAC-1), chloride intracellular channel protein 1 (CLIC1), guanine nucleotide-binding protein subunit beta (GBLP) and 14-3-3 protein gamma (14-3-3G) (19\% of total proteins), were found to play important roles in apoptosis and signal transduction. Additionally, six identified proteins ( 9 spots including their isoforms, $34.6 \%$ of

Table 1

Protein identification of differentially expressed proteins in arbutin-treated A375 cells at 72 h by MALDI-TOF MS and MS/MS

\begin{tabular}{|c|c|c|c|c|c|c|c|c|c|c|}
\hline \multirow[t]{2}{*}{ Spot no. } & \multirow[t]{2}{*}{ Protein name } & \multirow[t]{2}{*}{ Accession no. } & \multicolumn{2}{|c|}{$\mathrm{MW}(\mathrm{kDa})$ and $\mathrm{pI}$} & \multirow{2}{*}{$\begin{array}{l}\text { MS } \\
\text { method }\end{array}$} & \multirow{2}{*}{$\begin{array}{l}\text { Mowse } \\
\text { score }\end{array}$} & \multirow[t]{2}{*}{$\%$ Coverage } & \multirow{2}{*}{$\begin{array}{l}\text { No. of matched } \\
\text { peptides }\end{array}$} & \multirow[t]{2}{*}{ Fold-change } & \multirow[t]{2}{*}{ SD } \\
\hline & & & Apparent & Theoretical & & & & & & \\
\hline$\overline{1}$ & $\begin{array}{l}\text { Endoplasmin precursor (Heat shock protein } \\
90 \mathrm{kDa} \text { beta member 1) (ENPL) }\end{array}$ & P14625 & $98.0,4.10$ & $92.4,4.76$ & MS, MS/MS & 87,159 & 24,4 & 14,3 & -2.50 & 0.050 \\
\hline 2 & $\begin{array}{l}\text { Protein disulfide-isomerase A6 precursor } \\
\text { (PDIA6) }\end{array}$ & Q15084 & $64.50,4.50$ & $48.09,4.95$ & MS/MS &,- 54 &,- 2 &,- 1 & -1.00 & 0.055 \\
\hline 3 & Vimentin (VIME) & P08670 & $57.50,4.00$ & $53.62,5.06$ & MS, MS/MS & 143,160 & 51,12 & 17,4 & -2.00 & 0.125 \\
\hline 4 & Vimentin (VIME) & P08670 & $70.80,4.50$ & $53.62,5.06$ & MS, MS/MS & 156,126 & 47,9 & 17,3 & -1.50 & 0.017 \\
\hline 5 & $\begin{array}{l}\text { Heterogeneous nuclear ribonucleoprotein } \\
\text { H (HNRH1) }\end{array}$ & P31943 & $65.6,4.00$ & $49.20,5.89$ & MS, MS/MS & 41,51 & 28,4 & 7,1 & -1.20 & 0.125 \\
\hline 6 & $\begin{array}{l}\text { Heterogeneous nuclear ribonucleoproteins } \\
\text { A2/B1 (ROA2) }\end{array}$ & P22626 & $46.00,8.60$ & $37.41,8.97$ & MS, - & $123,-$ & $48,-$ & $14,-$ & -0.95 & 0.006 \\
\hline 7 & $\begin{array}{l}\text { Heterogeneous nuclear ribonucleoproteins } \\
\text { A2/B1 (ROA2) }\end{array}$ & P22626 & $43.10,8.30$ & $37.41,8.97$ & MS, MS/MS & 137,114 & 49,8 & 15,2 & -0.95 & 0.003 \\
\hline 8 & $\begin{array}{l}\text { Heterogeneous nuclear ribonucleoprotein } \\
\text { A1 (ROA1) }\end{array}$ & P09651 & $42.00,4.70$ & $38.82,9.26$ & MS, MS/MS & 72,191 & 31,14 & 9,4 & -2.45 & 0.011 \\
\hline 9 & $\begin{array}{l}\text { Heterogeneous nuclear ribonucleoprotein } \\
\text { A1 (ROA1) }\end{array}$ & P09651 & $42.00,4.90$ & $38.82,9.26$ & MS, MS/MS & 106,191 & 36,14 & 12,1 & -2.50 & 0.017 \\
\hline 10 & Ribonuclease inhibitor (RINI) & P13489 & $60.00,3.95$ & $49.94,4.71$ & MS, MS/MS & 50,47 & 27,2 & 9,1 & -2.45 & 0.013 \\
\hline 11 & Peroxiredoxin-1 (PRDX1) & Q06830 & $27.03,6.90$ & $22.10,8.27$ & MS, MS/MS & 63,117 & 42,15 & 7,2 & -2.00 & 0.054 \\
\hline 12 & Peroxiredoxin-1 (PRDX1) & Q06830 & $27.03,7.40$ & $22.10,8.27$ & MS, MS/MS & 75,137 & 47,15 & 8,2 & -2.10 & 0.111 \\
\hline 13 & $\begin{array}{l}\text { Malate dehydrogenase, mitochondrial } \\
\text { precursor (MDHM) }\end{array}$ & P40926 & $44.50,8.80$ & $35.52,8.92$ & MS, MS/MS & 96,266 & 41,16 & 11,2 & -2.05 & 0.008 \\
\hline 14 & $\begin{array}{l}\text { Voltage-dependent anion-selective channel } \\
\text { protein } 1 \text { (VDAC-1) }\end{array}$ & P21796 & $39.60,8.10$ & $30.85,8.62$ & MS, - & $55,-$ & $45,-$ & $7,-$ & +1.35 & 0.011 \\
\hline 15 & $\begin{array}{l}\text { Chloride intracellular channel } \\
\text { protein } 1 \text { (CLIC1) }\end{array}$ & O00299 & $37.50,4.65$ & $26.91,5.09$ & MS, MS/MS & $58,-$ & $39,-$ & $7,-$ & +1.30 & 0.013 \\
\hline 16 & $\begin{array}{l}\text { Guanine nucleotide-binding protein } \\
\text { subunit beta } \\
\text { 2-like (GBLP) }\end{array}$ & P63244 & $38.50,6.85$ & $35.05,7.60$ & MS, MS/MS & 85,49 & 42,4 & 10,1 & +2.20 & 0.110 \\
\hline 17 & $14-3-3$ protein gamma $(1433 \mathrm{G})$ & P61981 & $34.00,4.10$ & $28.28,4.80$ & -, MS/MS &,- 46 &,- 8 &,- 1 & +1.50 & 0.013 \\
\hline 18 & $\begin{array}{l}\text { Glyceraldehyde-3-phosphate } \\
\text { dehydrogenase (G3P) }\end{array}$ & P04406 & $46.00,8.75$ & $36.03,8.57$ & MS, MS/MS & 89,46 & 39,4 & 11,1 & -1.00 & 0.085 \\
\hline 19 & $\begin{array}{l}\text { Glyceraldehyde-3-phosphate } \\
\text { dehydrogenase (G3P) }\end{array}$ & P04406 & $46.50,4.75$ & $36.03,8.57$ & MS, - & $75,-$ & $37,-$ & $9,-$ & -1.50 & 0.013 \\
\hline 20 & $\begin{array}{l}\text { Glyceraldehyde-3-phosphate } \\
\text { dehydrogenase (G3P) }\end{array}$ & P04406 & $46.50,4.90$ & $36.03,8.57$ & MS, - & $77,-$ & $33,-$ & $11,-$ & -1.55 & 0.010 \\
\hline 21 & $\begin{array}{l}\text { Proteasome subunit beta type } 1 \\
\text { precursor (PSB1) }\end{array}$ & P20618 & $28.30,7.30$ & $26.47,8.27$ & MS, MS/MS & 54,54 & 42,13 & 9,2 & -1.55 & 0.018 \\
\hline 22 & $\begin{array}{l}\text { Inosine-5'-monophosphate } \\
\text { dehydrogenase } 2 \text { (IMDH2) }\end{array}$ & P12268 & $68.58,6.15$ & $55.77,6.44$ & MS, MS/MS & 85,84 & 30,3 & 12,1 & -1.50 & 0.026 \\
\hline 23 & $\begin{array}{l}\text { Glucose-6-phosphate 1-dehydrogenase } \\
\text { (G6PD) }\end{array}$ & P11413 & $65.50,6.10$ & $59.22,6.39$ & MS, MS/MS & 82,75 & 33,5 & 12,2 & -1.30 & 0.012 \\
\hline 24 & Alpha-enolase (ENOA) & P06733 & $60.00,6.50$ & $47.14,7.01$ & MS, MS/MS & 125,299 & 39,12 & 16,3 & -0.90 & 0.019 \\
\hline 25 & Alpha-enolase (ENOA) & P06733 & $60.00,6.20$ & $47.14,7.01$ & MS, MS/MS & 111, 217 & 38,12 & 14,3 & -0.90 & 0.015 \\
\hline 26 & $\begin{array}{l}\text { Tubulin alpha-ubiquitous } \\
\text { chain (TBAK) }\end{array}$ & P68361 & $71.30,4.50$ & $50.12,4.94$ & MS, MS/MS & 123,140 & 41,12 & 16,3 & +1.00 & 0.081 \\
\hline
\end{tabular}


Table 2

Protein ontology of identified proteins and some predicted interaction partners

\begin{tabular}{|c|c|c|c|c|c|}
\hline $\begin{array}{l}\text { Spot } \\
\text { no. }\end{array}$ & Protein name & Cellular component & Molecular function & Biological process & Predicted some interaction partners \\
\hline$\overline{1}$ & $\begin{array}{l}\text { Heat shock protein } 90 \\
\text { kDa beta member } 1 \\
\text { (ENPL) }\end{array}$ & $\begin{array}{l}\text { - Cytosol } \\
\text { - Melanosome stage 1-4 } \\
\text { - Endoplasmic } \\
\text { reticulum lumen } \\
\text { - Endoplasmic } \\
\text { reticulum membrane }\end{array}$ & $\begin{array}{l}\text { - Calcium ion binding } \\
\text { - Low-density lipoprotein } \\
\text { receptor binding } \\
\text { - RNA binding } \\
\text { - Virion binding }\end{array}$ & $\begin{array}{l}\text { - Anti-apoptosis } \\
\text { - Protein transport } \\
\text { - Response to hypoxia } \\
\text { - Sequestering of calcium ion }\end{array}$ & $\begin{array}{l}\text { - Grp75 } \\
\text { - Grp78 } \\
\text { - PDI A4 } \\
\text { - Receptor tyrosinase-protein kinase } \\
\text { erbB-2 } \\
\cdot \text { p53 }\end{array}$ \\
\hline 2 & $\begin{array}{l}\text { Protein disulfide- } \\
\text { isomerase A6 precursor } \\
\text { (PDIA6) }\end{array}$ & $\begin{array}{l}\text { - Endoplasmic reticulum } \\
\text { - Melanosome stage 1-4 } \\
\text { - ER-Golgi intermediate } \\
\text { compartment }\end{array}$ & $\begin{array}{l}\text { - Protein binding } \\
\text { - Protein disulfide isomerase } \\
\text { activity }\end{array}$ & - Protein folding & $\begin{array}{l}\text { - ERp31 } \\
\text { - GRP78 }\end{array}$ \\
\hline 3,4 & $\begin{array}{l}\text { Vimentin } \\
\text { (VIME) }\end{array}$ & $\begin{array}{l}\text { - Cytoplasm } \\
\text { - Intermediate filament }\end{array}$ & $\begin{array}{l}\text { - Protein binding } \\
\text { - Structural constituent of } \\
\text { cytoskeleton }\end{array}$ & - Cell motility & $\begin{array}{l}\text { - RAF-1 } \\
\text { - Proteosome subunit alpha type1 } \\
\text { - Protein kinase N1 } \\
\text { - p53 }\end{array}$ \\
\hline 5 & $\begin{array}{l}\text { Heterogeneous nuclear } \\
\text { ribonucleoprotein } \mathrm{H} \\
\text { (HNRH1) }\end{array}$ & $\begin{array}{l}\text { - Heterogeneous nuclear } \\
\text { ribonucleoprotein } \\
\text { complex }\end{array}$ & $\begin{array}{l}\text { - Poly(U) binding } \\
\text { - Protein binding }\end{array}$ & - RNA processing & $\begin{array}{l}\text { - Heterogeneous nuclear } \\
\text { ribonucleoproteins } \\
\text { - Polypyrimidine tract-binding } \\
\text { protein1 } \\
\text { - Splicing factors }\end{array}$ \\
\hline 6,7 & $\begin{array}{l}\text { Heterogeneous nuclear } \\
\text { ribonucleoproteins A2/B1 } \\
\text { (ROA2) }\end{array}$ & $\begin{array}{l}\text { - Heterogeneous nuclear } \\
\text { ribonucleoprotein } \\
\text { complex } \\
\text { - Spliceosome }\end{array}$ & $\begin{array}{l}\text { - Protein binding } \\
\text { - RNA binding } \\
\text { - Single-stranded telomeric } \\
\text { DNA binding }\end{array}$ & $\begin{array}{l}\text { - Nuclear mRNA splicing, via } \\
\text { spliceosome } \\
\text { - RNA transport }\end{array}$ & $\begin{array}{l}\text { - Heterogeneous nuclear } \\
\text { ribonucleoproteins } \\
\text { - Splicing factors } \\
\text { - NHP2-like protein1 } \\
\text { - ATP-dependent RNA helicase A }\end{array}$ \\
\hline 8,9 & $\begin{array}{l}\text { Heterogeneous nuclear } \\
\text { ribonucleoprotein A1 } \\
\text { (ROA1) }\end{array}$ & $\begin{array}{l}\text { - Cytoplasm } \\
\text { - Heterogeneous } \\
\text { nuclear ribonucleo- } \\
\text { protein complex } \\
\text { - Nucleoplasm } \\
\text { - Spliceosome }\end{array}$ & $\begin{array}{l}\text { - Protein binding } \\
\text { - Single-stranded DNA binding } \\
\text { - Single-stranded RNA binding }\end{array}$ & $\begin{array}{l}\text { - Nuclear import } \\
\text { - Nuclear mRNA splicing, via } \\
\text { spliceosome } \\
\text { - RNA export from nucleus }\end{array}$ & $\begin{array}{l}\text { - Polyadenylate binding protein } 2 \\
\text { - Splicing factors } \\
\text { - Nuclear DNA helicase II } \\
\text { - Nuclease sensitive element binding } \\
\text { protein1 } \\
\text { - Element binding protein1 }\end{array}$ \\
\hline 10 & $\begin{array}{l}\text { Ribonuclease inhibitor } \\
\text { (RINI) }\end{array}$ & $\begin{array}{l}\text { - Angiogenin-PRI } \\
\text { complex }\end{array}$ & $\begin{array}{l}\text { - Protein binding } \\
\text { - Ribonuclease inhibitor activity }\end{array}$ & $\begin{array}{l}\text { - mRNA catabolic process } \\
\text { - Regulation of angiogenesis }\end{array}$ & $\begin{array}{l}\text { - TNF-alpha } \\
\text { - NF-kappa-B essential modulator } \\
\text { - Receptor-interacting serine/threonine- } \\
\text { protein kinase } 3\end{array}$ \\
\hline 11,12 & $\begin{array}{l}\text { Peroxiredoxin-1 } \\
\text { (Thioredoxin peroxidase 2) } \\
\text { (PRDX1) }\end{array}$ & $\begin{array}{l}\text { - Cytoplasm } \\
\text { - Melanosome stage 1-4 }\end{array}$ & $\begin{array}{l}\text { - Redox regulation of the cell } \\
\text { - Participate in the signaling } \\
\text { cascades of growth factors and } \\
\text { TNF- } \alpha \text { by regulating the intracellular } \\
\text { concentrations of } \mathrm{H}_{2} \mathrm{O}_{2}\end{array}$ & $\begin{array}{l}\text { - Cell proliferation } \\
\text { - Skeletal development }\end{array}$ & $\begin{array}{l}\text { - Interleukin-4 } \\
\text { - Interferon regulatory factor } 3 \\
\text { - p53-regulated proteins PA26 }\end{array}$ \\
\hline 13 & $\begin{array}{l}\text { Malate dehydrogenase } \\
\text { (MDHM) }\end{array}$ & - Mitochondrion matrix & - 1-malate dehydrogenase activity & $\begin{array}{l}\text { - Citric acid cycle } \\
\text { - Gluconeogenesis }\end{array}$ & $\begin{array}{l}\text { - Citrate synthase } \\
\text { - Pyruvate carboxylase } \\
\text { - NADH-ubiquinone oxidoreductase }\end{array}$ \\
\hline 14 & $\begin{array}{l}\text { Voltage-dependent } \\
\text { anion-selective } \\
\text { channel protein } 1 \\
\text { (VDAC-1) }\end{array}$ & $\begin{array}{l}\text { - Mitochondrial outer } \\
\text { membrane } \\
\text { - Pore complex }\end{array}$ & $\begin{array}{l}\text { - Apoptogenic cytochrome c } \\
\text { release channel activity } \\
\text { - Protein binding } \\
\text { - Voltage-gated anion channel } \\
\text { porin activity }\end{array}$ & $\begin{array}{l}\text { - Anion transport } \\
\text { - Apoptotic program }\end{array}$ & $\begin{array}{l}\text { - Bcl-2-like protein } \\
\text { - Bcl-2 antagonist/killer } \\
\text { - Bcl-2 } \\
\text { - BAX } \\
\text { - RAF proto-oncogene }\end{array}$ \\
\hline 15 & $\begin{array}{l}\text { Chloride intracellular } \\
\text { channel protein } 1 \\
\text { (CLIC1) }\end{array}$ & $\begin{array}{l}\text { - Brush border } \\
\text { - Cytoplasm } \\
\text { - Membrane fraction } \\
\text { - Nuclear envelope } \\
\text { - Soluble fraction }\end{array}$ & $\begin{array}{l}\text { - Chloride channel activity } \\
\text { - Protein binding }\end{array}$ & $\begin{array}{l}\text { - Chloride transport } \\
\text { - Signal transduction }\end{array}$ & $\begin{array}{l}\text { - Interleukin-2 receptor } \\
\text { - } 14-3-3 \text { protein gamma } \\
\text { - Protein kinase A anchoring protein } 9 \\
\text { - Trafficking protein particle complex }\end{array}$ \\
\hline 16 & $\begin{array}{l}\text { Guanine nucleotide- } \\
\text { binding protein subunit } \\
\text { beta 2-like } \\
\text { (GBLP) }\end{array}$ & • Cytoplasm & - Protein kinase $\mathrm{C}$ binding & $\begin{array}{l}\text { - Cell proliferation } \\
\text { - Cell differentiation } \\
\text { - Signal transduction } \\
\text { - Intracellular protein } \\
\text { transportation }\end{array}$ & $\begin{array}{l}\text { - Guanine nucleotide-binding protein } \\
\text { subunits } \\
\text { - PKC }\end{array}$ \\
\hline 17 & $\begin{array}{l}14-3-3 \text { protein gamma } \\
\text { (Protein kinase } C \\
\text { inhibitor protein } 1 \\
(1433 G)\end{array}$ & - Cytoplasm & $\begin{array}{l}\text { - Insulin-like growth factor } \\
\text { receptor binding } \\
\text { - Protein kinase } C \text { binding } \\
\text { - Protein kinase } C \text { inhibitor } \\
\text { activity }\end{array}$ & $\begin{array}{l}\text { - Regulation of signal } \\
\text { transduction } \\
\text { - Regulation of apoptosis } \\
\text { - Cell cycle progression } \\
\text { - Regulation of DNA } \\
\text { replication } \\
\text { - Regulation of neuron } \\
\text { differentiation } \\
\text { - Regulation of synaptic } \\
\text { plasticity }\end{array}$ & $\begin{array}{l}\text { - RAF proto-oncogene serine/threonine } \\
\text { protein kinase } \\
\text { - PKC } \\
\text { - Proto-oncogene tyrosine-protein } \\
\text { kinase Src } \\
\text { - Kinesin like protein } \\
\text { - } 14-3-3 \text { protein epsilon } \\
\text { - p53 }\end{array}$ \\
\hline $\begin{array}{l}18,19 \\
20\end{array}$ & $\begin{array}{l}\text { Glyceraldehyde-3- } \\
\text { phosphate } \\
\text { dehydrogenase (G3P) }\end{array}$ & - Cytoplasm & $\begin{array}{l}\text { - Glyceraldehyde-3-phosphate } \\
\text { dehydrogenase } \\
\text { - Protein binding }\end{array}$ & $\begin{array}{l}\text { - Glycolysis } \\
\text { - Maintenance of cell } \\
\text { function }\end{array}$ & $\begin{array}{l}\text { - Phosphoglycerate kinase } 1 \\
\text { - Triosephosphate isomerase } \\
\text { - Transketolase }\end{array}$ \\
\hline 21 & $\begin{array}{l}\text { Proteasome subunit } \\
\text { beta type } 1 \text { precursor (PSB1) }\end{array}$ & $\begin{array}{l}\text { - Cytoplasm } \\
\text { - Nucleus } \\
\text { - Proteasome complex }\end{array}$ & $\begin{array}{l}\text { - Proteinase } \\
\text { - Protein binding }\end{array}$ & $\begin{array}{l}\text { - Protein regulation and } \\
\text { degradation }\end{array}$ & - Proteasome subunits \\
\hline
\end{tabular}


Table 2 (continued)

\begin{tabular}{|c|c|c|c|c|c|}
\hline $\begin{array}{l}\text { Spot } \\
\text { no. }\end{array}$ & Protein name & Cellular component & Molecular function & Biological process & Predicted some interaction partners \\
\hline 22 & $\begin{array}{l}\text { Inosine-5'- } \\
\text { monophosphate } \\
\text { dehydrogenase } 2 \\
\text { (IMDH2) }\end{array}$ & - Cytoplasm & $\begin{array}{l}\text { - IMP dehydrogenase activity } \\
\text { - Rate-limiting enzyme in the de } \\
\text { novo synthesis of guanine } \\
\text { nucleotides } \\
\text { - Protein binding }\end{array}$ & $\begin{array}{l}\text { - Involved in the regulation } \\
\text { of cell growth } \\
\text { - Guanine nucleotides } \\
\text { biosynthesis } \\
\text { - Growth progression of } \\
\text { some tumors }\end{array}$ & $\begin{array}{l}\text { - Inosine-5'monophosphate } \\
\text { dehydrogenase } 1 \\
\text {-GMP synthase, } \\
\text {-GMP reductase } 1 \text { and } 2 \\
\text {-AMP deaminase } 1 \text { and } 3\end{array}$ \\
\hline 23 & $\begin{array}{l}\text { Glucose-6-phosphate } \\
\text { 1-dehydrogenase } \\
\text { (G6PD) }\end{array}$ & - Cytoplasm & $\begin{array}{l}\text { - Glucose-6-phosphate } \\
\text { dehydrogenase activity }\end{array}$ & $\begin{array}{l}\text { - Glucose 6-phosphate } \\
\text { utilization } \\
\text { - Pentose-phosphate shunt }\end{array}$ & $\begin{array}{l}\text { - NF-kappa-B essential modulator } \\
\text { - cGMP-dependent protein kinase } 1 \\
\text { - Glucose-6-phosphate isomerase }\end{array}$ \\
\hline 24,25 & Alpha-enolase (ENOA) & $\begin{array}{l}\text { - Cytoplasm } \\
\text { - Cell membrane } \\
\text { - Nucleus }\end{array}$ & $\begin{array}{l}\text { - Phosphopyruvate hydratase } \\
\text { activity } \\
\text { - Transcription corepressor activity } \\
\text { - Transcription factor activity }\end{array}$ & $\begin{array}{l}\text { - Negative regulation of cell } \\
\text { growth } \\
\text { - Negative regulation of } \\
\text { transcription from RNA } \\
\text { polymerase II promoter }\end{array}$ & $\begin{array}{l}\text { - Pyruvate kinase isozymes M1/M2 } \\
\text { - Myc proto-oncogene protein } \\
\text { - Adenylate kinase isoenzyme } 2\end{array}$ \\
\hline 26 & $\begin{array}{l}\text { Tubulin alpha- } \\
\text { ubiquitous chain } \\
\text { (TBAK) }\end{array}$ & - Cytosol & $\begin{array}{l}\text { - Including motility } \\
\text { - Maintenance of cell shape } \\
\text { - Intracellular trafficking of } \\
\text { macromolecules } \\
\text { and organelles } \\
\text { - Mitosis }\end{array}$ & - & $\begin{array}{l}\text { - Tubulin beta and alpha chains } \\
\text { - Kinesin-like protein KIF1A } \\
\text { - Actin }\end{array}$ \\
\hline
\end{tabular}

total proteins), nuclear ribonucleoprotein $\mathrm{H}$ (HNRH1), ribonucleoproteins A2/B1 (ROA2), ribonucleoprotein A1 (ROA1), ribonuclease inhibitor (RINI), 14-3-3G and alpha-enolase (ENOA), function in nucleic acid processing or transcriptional regulation. Moreover, four identified proteins (seven spots including their isoforms, $27 \%$ of total proteins), malate dehydrogenase (MDHM), glyceraldehyde-3-phosphate dehydrogenase (G3P), glucose-6-phosphate 1-dehydrogenase (G6PD) and ENOA, are involved in carbohydrate metabolism pathways and have additional functions in the regulation of cell growth and maintenance of cellular functions.

\subsection{Validation by western blotting or RT-PCR}

Among the identified proteins, vimentin (VIME), 4-3-3G, peroxiredoxin-1 (PRDX1), heat shock protein $90 \mathrm{kDa}$ beta member 1(ENPL), inosine-5'-monophosphate dehydrogenase 2 (IMDH2), ENOA, VDAC-1 and p53 were validated by RT-PCR (Fig. 2). The results of protein and gene expression levels of eight differentially expressed proteins were in agreement with the 2-D PAGE expression data. 14-3-3G, VDAC-1 and p53 proteins were upregulated in the arbutin-treated A375 cells, whereas VIME, PRDX1, ENPL, IMDH2 and ENOA were downregulated in the arbutin-treated A375 cells.

\subsection{Correlation of differentially expressed proteins with tumorigenesis}

Combining the interaction and pathway databases and literature of STRING, BioCarta, KEGG and PubMed, we built a hypothetical model of a protein interaction network corresponding to the regulation of apoptosis in tumorigenesis wherein 14 differentially expressed proteins in arbutin-treated A375 cells, PDIA6, ENPL, RINI, VDAC-1, CLIC1, PRDX1, VIME, 14-3-3G, PSB1, GBLP, G3P, ENOA, G6PD and MDHM, are correlated (Fig. 3). This network can be divided to four network groups: stress responding proteins, proteins involved in melanogenesis, proteins involved in the regulation of apoptosis and proteins involved in energy metabolism. Among these proteins, there are nine proteins that interacted with protein kinases: ENPL, VIME, RINI, VDAC-1, CLIC1, 14-3-3G, G6PD, GBLP and ENOA; four proteins interacted with p53: ENPL, VIME, PRDX1 and 14-3-3G; two proteins interacted with Bcl2 protein: 14-3-3G and VDAC-1; four proteins were involved in energy metabolism: G3P, ENOA, G6PD and MDHM; and three proteins were involved in ion channels or ion sequestering: VDAC-1, CLIC1 and ENPL. The interaction scores between the proteins were determined using the STRING database (Table S2). However, some of the interactions were not scored since the interactions had already been reported in the literature. We suggest that arbutin changes the protein expression of A375 cells and may cause some changes in cellular physical and metabolic events that are involved in the regulation of melanogenesis and apoptosis in A375 cells.

\section{Discussion}

According to our previous study that investigated the toxicogenomic effects of arbutin on the gene expression profile of A375 cells using microarray [8], there was no growth inhibition or morphological change of A375 cells after $72 \mathrm{~h}$ in the presence of arbutin $(8 \mu \mathrm{g} / \mathrm{ml})$, using a mild arbutin concentration for human skin safety. The gene expression data showed some tumor suppressor genes as biomarkers in A375 cells. Although one gene makes one protein, the posttranslational modifications of proteins can lead to changes in biological and physiological functions that may not be caused by gene modification. In order to examine the effects of arbutin on the protein expression levels in A375 cells, the same concentration of arbutin $(8 \mu \mathrm{g} / \mathrm{ml})$, although with different treatment times of 24,48 and $72 \mathrm{~h}$, was used in this study.

Among the differentially expressed proteins validated by RT-PCR, VIME, 14-3-3G and VDAC-1 were found to interact with Raf-1. VIME, which is one of the intermediate filaments, is the major cytoskeleton component in developing cancer cells. VIME is phosphorylated by Raf1 -associated vimentin kinase, resulting in the regulation of the vimentin filament structure [11]. The protein is also a target for phosphorylation by PKC, which is involved in many signal transduction pathways, including the regulation of organelle movement in melanophores [12-14], regulation of cytoskeletal function and programmed cell death (apoptosis) [15-18]. In carcinoma cell lines, the downregulation of VIME expression resulted in impaired migration and adhesion [19]. Likewise, our RT-PCR results of VIME showed that VIME was downregulated in arbutin-treated A375 cells, suggesting an effect on the intermediate filament network, ultimately leading to impaired migration and adhesion of A375 cells. Since VIME is involved in the regulation of stress response proteins [20], the heat shock protein ENPL, also determined in this study to be downregulated in A375 cells, may be partially involved in VIME regulation. ENPL is a member of the heat shock protein HSP90 that can be found in the melanosome. It is well known that heat shock proteins are overexpressed in a wide range of human cancers and are implicated in tumor cell proliferation, differentiation, and recognition by the immune system [21-24]. Therefore, the downregulated ENPL in 
Expression ratio against $\beta$-actin

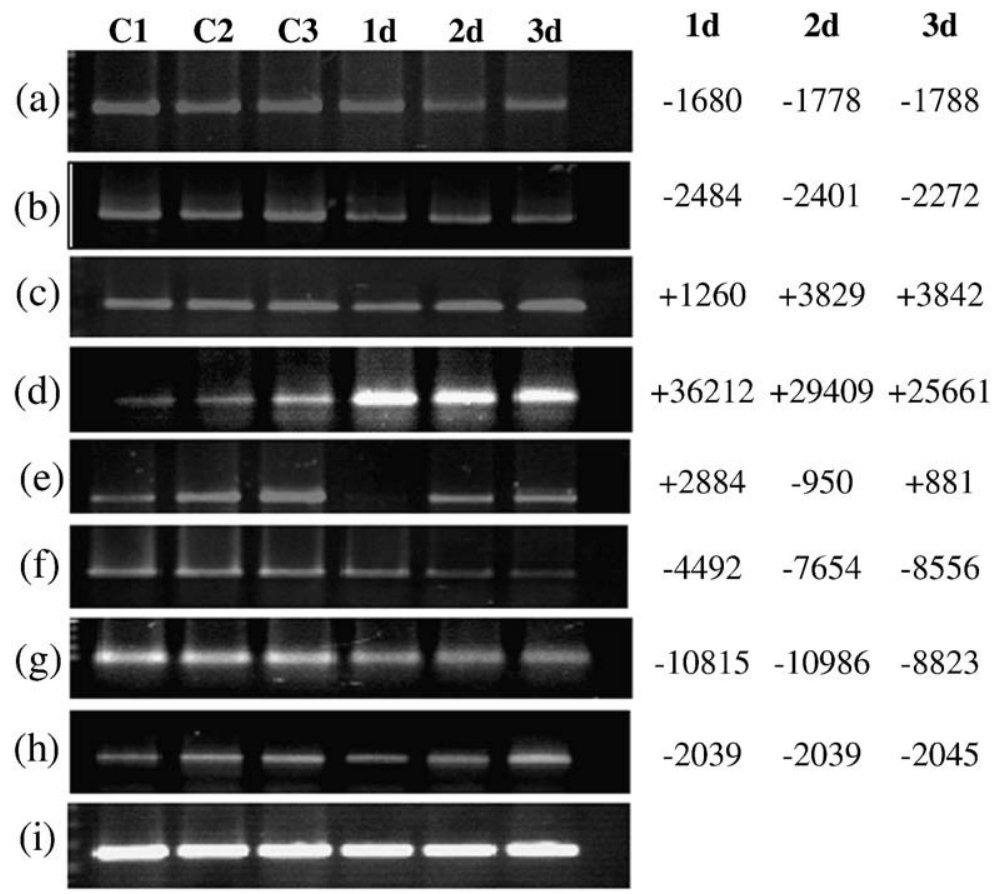

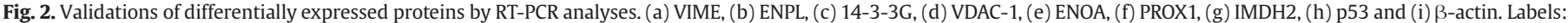
c1, c2 and c3 indicate the control group at 24,48 and 72 h, respectively, and d1, d2 and d3 indicate the treatment groups at 24,48 and 72 h, respectively.

arbutin-treated A375 cells may suppress the tumor progression and metastasis as well as the decreased immune response. In addition, ENPL was found to be correlated with other types of heat shock proteins and also to interact with p53 and 14-3-3 proteins, which both play important roles in apoptosis.
14-3-3 molecules act as control points for many cellular processes $[25,26]$ and therefore play significant roles in the determination of a cell's fate and in several apoptotic pathways in animals. 14-3-3 proteins have been reported to have important interactions with other regulatory proteins. They display important anti-apoptotic

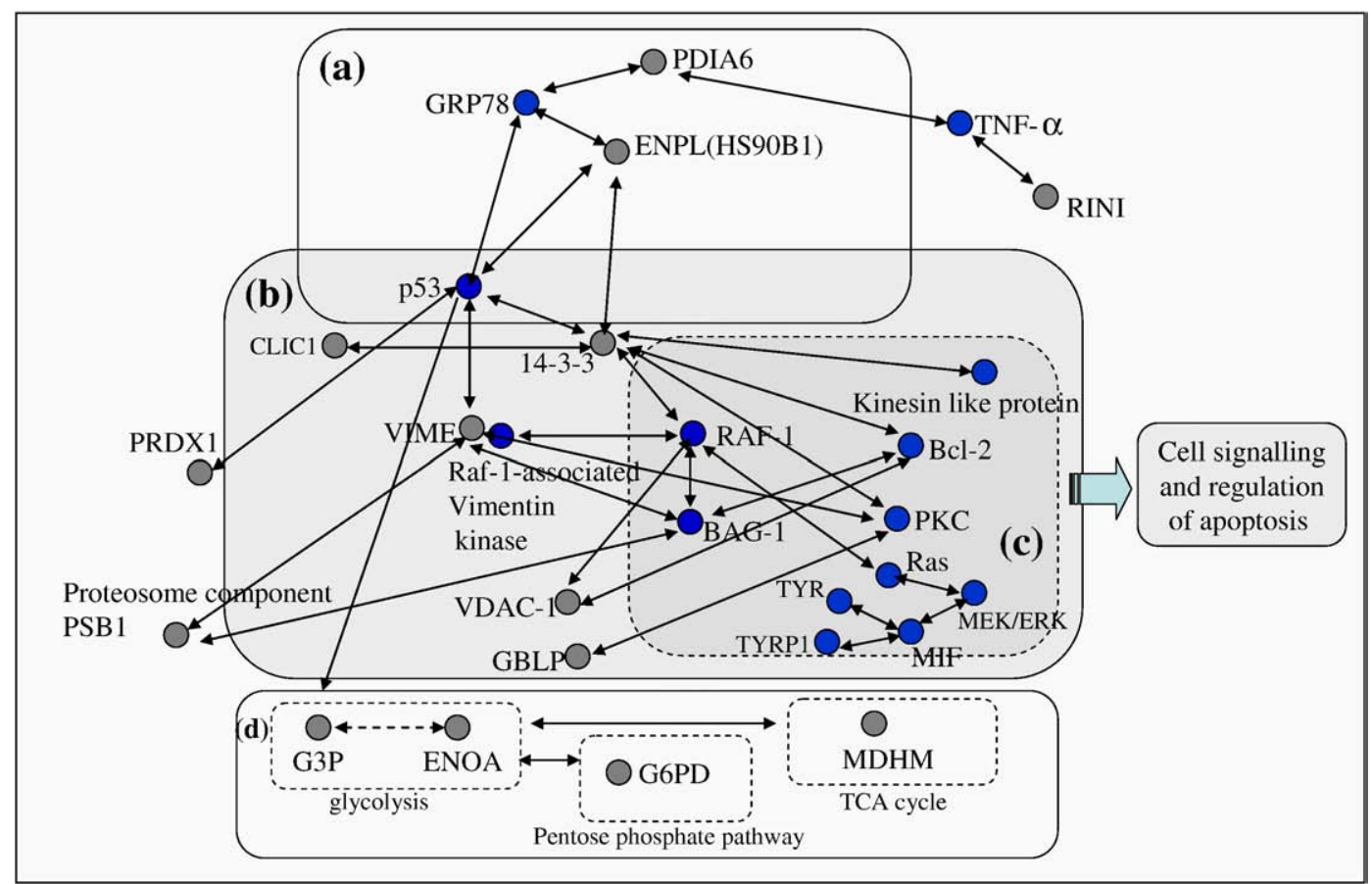

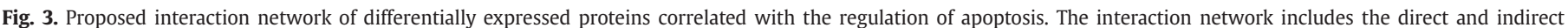

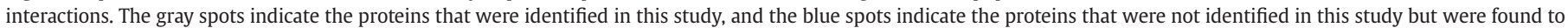

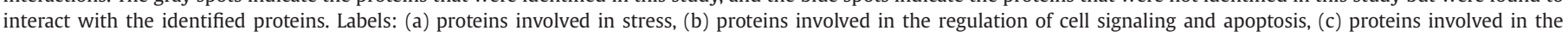
melanogenesis pathway and (d) proteins involved in energy metabolism. 
characteristics by inhibiting the pro-apoptotic BAD (Bcl-2-antagonist of cell death) and transcription factor FKHRL-1. The major roles ascribed to the mammalian 14-3-3 proteins include activation of tyrosine and tryptophan hydroxylases, regulation of protein kinase $C$ (PKC), exocytosis, especially in mediating interactions between protein kinases and other signal transduction proteins [25]. 14-3-3 was found to activate the Ras-Raf mitogenic pathway. The protein can elicit a physiologically significant activation of Raf- 1 in mammalian cells [27]. Since 14-3-3 proteins are involved in a great number of interactions, the effects of knocking out or overexpressing specific 143-3 genes or 14-3-3 target genes will likely have effects on other 14-33-regulated cellular processes. Previous studies found that 14-3-3 proteins activate p53 function in vivo [28,29]; thus, the upregulation of 14-3-3G protein expression in arbutin-treated A375 cells may imply that arbutin can stimulate changes within signal transduction pathways by stabilizing or increasing the expression of the protein 14-3-3. The increase in protein expression might involve a critical response of the cell proliferation and differentiation and on apoptosis of the arbutin-treated A375 cells. As shown in Fig. 2, the change in the expression of 14-3-3 might alter the biological activities of p53, RAF-1, CLIC1, ENPL, Bcl2 and kinesin-like proteins.

Interestingly, the partial functions of ENPL and VDAC-1 in ion channel activity or ion sequestering ability are involved in energy metabolism, which is important for the cell's survival. Considering the cellular location of these proteins to the cell membrane and mitochondria implies that the effect of arbutin on membrane and mitochondria may cause changes in the cellular physiology and metabolic events. VDAC-1, a major mitochondrial outer membrane transporter, is one of the permeability transition (PT) components [30-32] and plays an important role in apoptosis by participating in the release of intermembrane space proteins, including cytochrome c, and being involved in $\mathrm{Ca}^{2+}$ signaling [33-38]. VDAC-1 has also been found to be correlated with the Bax/Bak and Bcl-2 families of proteins, which are essential regulators of cell death and exert their primary pro- or anti-apoptotic roles at the mitochondrial outer membrane [39-41]. Therefore, the upregulation of VDAC-1 expression in arbutintreated A375 cells may play a crucial role in the processes of mitochondria-mediated apoptosis, mitochondrial membrane permeability transition and intracellular $\mathrm{Ca}^{2+}$ transport [42].

On the other hand, p53 tumor suppressor proteins have been reported to have additional roles in the regulation of glycolysis [43]. In this study, four proteins identified as glycolytic enzymes, G3P, ENOA, G6PD and MDHM, were found to be involved in glucose metabolism, but only ENOA was validated by RT-PCR. The low expression of ENOA in arbutin-treated A375 cells may be implicated in metastasis and also change the correlated signaling pathways that are able to modulate cellular metabolism. In addition to the regulation of glycolysis in cancer cells, p53 also has functions in the regulation of both apoptosis and intracellular reactive oxygen species (ROS) levels [44-47]. Additionally, peroxiredoxin-1 (PROX1) is one of the antioxidant enzymes and is involved in cellular proliferation and differentiation [48]. The cell survival-enhancing function of PROX1 is traditionally attributed to its reactive oxygen species-removing capacity [49]. Indeed, lower PROX1 activity increased reactive oxygen species levels and induced p53 expression [50]. Therefore, the p53 status is a major determinant of the decreased PROX1 expression on tumor growth and the response of cells to treatment. This agrees with our results of upregulated p53 and downregulated PROX1 in arbutin-treated A375 cells.

In addition to energy metabolism, arbutin may also affect nucleotide metabolism since ribonucleoproteins (HNRH1, ROA2, ROA1), ribonuclease inhibitor (RINI), and inosine-5'-monophosphate dehydrogenase (IMDH2) were affected by arbutin treatment. IMDH2 is a regulatory enzyme of guanine nucleotide biosynthesis and is also strategically positioned in the metabolic pathway of thiopurines [51]. Increased enzymatic activity of IMPDH2 and its mRNA expression level have been observed in rapidly proliferating tumor cells [52-55]. The IMDH2 protein has been established as an anticancer target [56]. Therefore, the downregulated IMDH2 may suppress nucleotide biosynthesis, cell proliferation and the malignancy of A375 cells.

According to our proteomic results, many identified proteins, including heat shock proteins, glucose regulated proteins and other proteins, were found to be correlated with p53, which is the major suppressor protein and plays significant roles in many biological processes in cancer development. Moreover, the p53 protein has biological roles in pigmentation. Tumor suppressor p53 could downregulate the tissue-specific expression of the tyrosinase gene in human melanoma cell lines [57,58]. Therefore, arbutin has potent effects on both protein and gene expression levels and leads to the suppression of the melanogenesis and tumorigenesis of A375 cells. However, the correlation of protein and gene expressions and their biological functions will be further studied for better understanding the biological effect of arbutin on the biology of A375 malignant melanoma cancer cells.

In summary, we identified a number of differentially expressed proteins in arbutin-treated A375 cells. Most of these proteins were key players in a wide variety of cellular processes, including cell proliferation, regulation of protein expression and signaling pathways. Interestingly, our proposed interaction network showed the correlation of some differentially expressed proteins with the regulation of apoptosis, which may lead to the suppression of the melanogenesis and tumorigenesis of cancer cells. However, further functional studies of these proteins may lead to a deeper understanding of the pathogenic mechanisms and cellular responses to arbutin treatment.

\section{Acknowledgements}

This study was supported by a grant from the Chung Shan Medical University (CSMU 96-OM-B-045) and the Thematic Project in The Life Science, Academia Sinica (94C008-2).

\section{Appendix A. Supplementary data}

Supplementary data associated with this article can be found, in the online version, at doi:10.1016/j.bbapap.2008.09.023.

\section{References}

[1] A.K. Chakraborty, Y. Funasaka, M. Komoto, M. Ichihashi, Effect of arbutin on melanogenic proteins in human melanocytes, Pigment Cell Res. 11 (1998) 206-212.

[2] K. Maeda, M. Fukuda, Arbutin: mechanism of its depigmenting action in human melanocyte culture, J. Pharmacol. Exp. Ther. 276 (1996) 765-769.

[3] M. Nakajima, I. Shinoda, Y. Fukuwatari, H. Hayasawa, Arbutin increases the pigmentation of cultured human melanocytes through mechanisms other than the induction of tyrosinase activity, Pigment Cell Res. 11 (1998) 12-17.

[4] T.P. Dooley, Topical skin depigmentation agents: current products and discovery of novel inhibitors of melanogenesis, J. Dematol. Treat. 7 (1997) 188-200.

[5] J.F. Hermanns, L. Petit, O. Martalo, C. Pierard-Franchimont, G. Cauwenbergh, G.E Pierard, Unraveling the patterns of subclinical pheomelanin-enriched facial hyperpigmentation: effect of depigmenting agents, Dermatology 201 (2000) 118-122.

[6] E. Frenk, Treatment of melasma with depigmenting agents, Melasma: New Approaches to Treatment, Martin Dunitz Ltd., London, 1995, pp. 9-15.

[7] M. Blaut, A. Braune, S. Wunderlich, P. Sauer, H. Schneider, H. Glatt, Mutagenicity of arbutin in mammalian cells after activation by human intestinal bacteria, Food Chem. Toxicol. 44 (2006) 1940-1947.

[8] S.L. Cheng, R.H. Liu, J.N. Sheu, S.T. Chen, S. Sinchaikul, G.J. Tsay, Toxicogenomics of A375 human malignant melanoma cells treated with arbutin, J. Biomed. Sci. 14 (2007) 87-105.

[9] V.P. Eswarakumar, I. Lax, J. Schlessinger, Cellular signaling by fibroblast growth factor receptors, Cytokine Growth Factor Rev. 16 (2005) 139-149.

[10] C.G. L'Hote, M.A. Knowles, Cell responses to FGFR3 signaling: growth, differentiation and apoptosis, Exp. Cell. Res. 304 (2005) 417-431.

[11] P. Janosch, A. Kieser, M. Eulitz, J. Lovric, G. Sauer, M. Reichert, F. Gounari, D. Büscher, M. Baccarini, H. Mischak, W. Kolch, The Raf-1 kinase associates with vimentin kinases and regulates the structure of vimentin filaments, FASEB J. 14 (2000) 2008-2021. 
[12] J. Ivaska, K. Vuoriluoto, T. Huovinen, I. Izawa, M. Inagaki, P.J. Parker, PKC-mediated phosphorylation of vimentin controls integrin recycling and motility, EMBO J. 24 (2005) 3834-3845.

[13] A.R. Reilein, I.S. Tint, N.I. Peunova, G.N. Enikolopov, V.I. Gelfand, Regulation of organelle movement in melanophores by protein kinase $A(P K A)$, protein kinase $C$ (PKC), and protein phosphatase 2A (PP2A), J. Cell Biol. 142 (1998) 803-813.

[14] J. Szalay, P. Bruno, R. Bhati, J. Adjodha, D. Schueler, V. Summerville, R. Vazeos, Associations of PKC isoforms with the cytoskeleton of B16F10 melanoma cells, J. Histochem. Cytochem. 49 (2001) 49-65.

[15] K. Nakanishi, M. Maruyama, T. Shibata, N. Morishima, Identification of a caspase- 9 substrate and detection of its cleavage in programmed cell death during mouse development, J. Biol. Chem. 276 (2001) 41237-41244.

[16] Y. Byun, F. Chen, R. Chang, M. Trivedi, K.J. Green, V.L. Cryns, Caspase cleavage of vimentin disrupts intermediate filaments and promotes apoptosis, Cell Death Differ. 8 (2001) 443-450.

[17] K. Müller, S. Dulku, S.J. Hardwick, J.N. Skepper, M.J. Mitchinson, Changes in vimentin in human macrophages during apoptosis induced by oxidised low density lipoprotein, Atherosclerosis 156 (2001) 133-144.

[18] X. Yang, J. Wang, C. Liu, W.E. Grizzle, S. Yu, S. Zhang, S. Barnes, W.J. Koopman, J.D. Mountz, R.P. Kimberly, H.G. Zhang, Cleavage of p53-vimentin complex enhances tumor necrosis factor-related apoptosis-inducing ligand-mediated apoptosis of rheumatoid arthritis synovial fibroblasts; cell injury, repair, aging and apoptosis, Am. J. Pathol. 167 (2005) 705-719.

[19] L. McInroy, A. Maatta, Down-regulation of vimentin expression inhibits carcinoma cell migration and adhesion, Biochem. Biophys. Res. Comm. 360 (2007) 109-114.

[20] G. Benitez-King, PKC activation by melatonin modulates vimentin intermediate filament organization in N1E-115 cells, J. Pineal. Res. 29 (2000) 8-14.

[21] S. Lindquist, E.A. Craig, The heat shock proteins, Anuu. Rev. Genet. 22 (1998) 631-637.

[22] H.M. Beere, "The stress of dying": the role of heat shock proteins in the regulation of apoptosis, J. Cell Sci. 117 (2004) 2641-2651.

[23] W.B. Pratt, D.O. Toft, Regulation of signaling protein function and trafficking by the hsp90/hsp70-based chaperone machinery, Exp. Biol. Med. 228 (2003) 111-133.

[24] D.R. Ciocca, S.K. Calderwood, Heat shock proteins in cancer: diagnostic, prognostic predictive, and treatment implications, Cell Stress Chaperones 10 (2005) 86-103.

[25] A. Aitken, 14-3-3 and its possible role in coordinating multiple signalling pathways, Trends Cell Biol. 6 (1996) 341-347.

[26] G. Tzivion, J. Avruch, 14-3-3 proteins: active cofactors in cellular regulation by serine/threonine phosphorylation, J. Biol. Chem. 277 (2002) 3061-3064.

[27] S. Li, P. Janosch, M. Tanji, G.C. Rosenfeld, J.C. Waymire, H. Mischak, W. Kolch, J.M Sedivy, Regulation of Raf-1 kinase activity by the 14-3-3 family of proteins, EMBO 14 (1995) 685-696.

[28] T.D. Halazonetics, L.J. Davis, A.N. Kandil, Wild type p53 adopts a "mutant"-like conformation when bound to DNA, EMBO J. 12 (1993) 1021-1028.

[29] J.L.F. Waterman, J.L. Shenk, T.D. Halozonetis, The dihedral symmetry of the p53 tetramerization domain mandates a conformational switch upon DNA binding, EMBO J. 14 (1995) 512-519.

[30] G. Kroemer, N. Zamzami, S.A. Susin, Mitochondrial control of apoptosis, Immunol. Today 18 (1997) 44-51.

[31] M. Crompton, S. Virji, V. Doyle, N. Johnson, J.M. Ward, The mitochondrial permeability transition pore, Biochem. Soc. Symp. 66 (1999) 167-179.

[32] A.P. Halestrap, E. Doran, J.P. Gillespie, A. O'Toole, Mitochondria and cell death Biochem. Soc. Trans. 28 (2000) 170-177.

[33] F. Di-Lisa, G. Gambassi, H. Spurgeon, R.G. Hansford, Intramitochondrial free calcium in cardiac myocytes in relation to dehydrogenase activation, Cardiovasc Res. 2 (1993) 1840-1844.

[34] M.J. Berridge, M.D. Bootman, P. Lipp, Calcium - a life and death signal, Nature 395 (1998) 645-648.

[35] M. Zoratti, I. Szabo, The mitochondrial permeability transition, Biochim. Biophys. Acta 1241 (1995) 139-176.

[36] P. Bernardi, Mitochondrial transport of cations: channels, exchangers, and permeability transition, Physiol. Rev. 79 (1999) 1127-1155.

[37] A.M. Cesura, E. Pinard, R. Schubenel, V. Goetschy, A. Friedlein, H. Langen, P. Polcic M.A. Forte, P. Bernardi, J.A. Kemp, The voltage-dependent anion channel is the target for a new class of inhibitors of the mitochondrial permeability transition pore, J. Biol. Chem. 278 (2003) 49812-49818.

[38] V. Shoshan-Barmatz, D. Gincel, The voltage-dependent anion channel: characterization, modulation, and role in mitochondrial function in cell life and death, Cell Biochem. Biophys. 39 (2003) 279-292.

[39] S. Shimizu, M. Narita, Y. Tsujimoto, Bcl-2 family of proteins target mitochondrial channel VDAC to regulate apoptogenic cytochrome c release, Nature 399 (1999) 483-487.

[40] S. Shimizu, T. Ide, T. Yanagida, Y. Tujimoto, Electrophysiological study of a novel large pore formed by Bax and VDAC, which is permeable to cytochrome c, J. Biol. Chem. 275 (2000) 12321-12325.

[41] S. Shimizu, A. Konishi, T. Kodama, Y. Tsujimoto, BH4 domain of anti-apoptotic Bcl2 family members closes VDAC, and inhibits apoptotic mitochondrial changes and cell death, Proc. Natl. Acad. Sci. U. S. A. 97 (2000) 3100-3105.

[42] H. Zaid, S. Abu-Hamad, A. Israelson, I. Nathan, V. Shoshan-Barmatz, The voltagedependent anion channel-1 modulates apoptotic cell death, Cell Death Differ. 12 (2005) 751-760.

[43] S. Macip, M. Igarashi, P. Berggren, J. Yu, S.W. Lee, S.A. Aaronson, Influence of induced reactive oxygen species in p53-mediated cell fate decisions, Mol. Cell. Biol. 23 (2003) 8576-8585.

[44] G.C. Chang, K.J. Liu, C.L. Hsieh, T.S. Hu, S. Charoenfuprasert, H.K. Liu, K.T. Luh, L.H. Hsu, C.W. Wu, C.C. Ting, C.Y. Chen, K.C. Chen, T.Y. Yang, T.Y. Chou, W.H. Wang, J. Whang-Peng, N.Y. Shih, Identification of alpha-enolase as an autoantigen in lung cancer: its overexpression is associated with clinical outcomes, Clin. Cancer Res. 12 (2006) 5746-5754.

[45] T.M. Johnson, Z.X. Yu, V.J. Ferans, R.A. Lowenstein, T. Finkel, Reactive oxygen species are downstream mediators of p53-dependent apoptosis, Proc. Natl. Acad. Sci. U. S. A. 93 (1996) 11848-11852.

[46] P.F. Li, R. Dietz, R. von Harsdorf, P53 regulates mitochondrial membrane potential through reactive oxygen species and induces cytochrome c-independent apoptosis blocked by Bcl-2, EMBO J. 18 (1993) 6027-6036.

[47] K. Polyak, Y. Xia, J.L. Zweier, K.W. Kinzler, B. Vogelstein, A model for p53-induced apoptosis, Nature 389 (1997) 300-305.

[48] L.H. Butterfield, A. Merino, S.H. Golub, H. Shau, From cytoprotection to tumor suppression: the multifactorial role of peroxiredoxins, Antioxid. Redox. Signal. 1 (1999) 385-401.

[49] Y.J. Kim, J.Y. Ahn, P. Liang, C. Ip, Y. Zhang, Y.M. Park, Human prx1 gene is a target of Nrf2 and is up-regulated by hypoxia/reoxygenation: implication to tumor biology, Cancer Res. 67 (2007) 546-554.

[50] M.F. Chen, W.C. Chen, C.T. Wu, P.Y. Lin, H. Shau, S.K. Liao, C.T. Yang, K.D. Lee, p53 status is a major determinant of effects of decreasing peroxiredoxin 1 expression on tumor growth and response of lung cancer cells to treatment, Int. J. Rad. Oncol. Biol. Phys. 66 (2006) 1461-1472.

[51] M.B. Cohen, W. Sadee, Contributions of the depletions of guanine and adenine nucleotides to the toxicity of purine starvation in the mouse T lymphoma cell line, Cancer Res. 43 (1983) 1587-1591.

[52] F.R. Collart, C.B. Chubb, B.L. Mirkin, E. Huberman, Increased inosine-5'-phosphate dehydrogenase gene expression in solid tumor tissues and tumor cell lines, Cancer Res. 52 (1992) 5826-5828.

[53] R.C. Jackson, G. Weber, H.P. Morris, IMP dehydrogenase, an enzyme linked with proliferation and malignancy, Nature 256 (1975) 331-333.

[54] Y. Natsumeda, S. Ohno, H. Kawasaki, Y. Konno, G. Weber, K. Suzuki, Two distinct cDNAs for human IMP dehydrogenase, J. Biol. Chem. 265 (1990) 5292-5295.

[55] A.G. Zimmermann, J.J. Gu, J. Laliberté, B.S. Mitchell, Inosine-5'-monophosphate dehydrogenase: regulation of expression and role in cellular proliferation and $\mathrm{T}$ lymphocyte activation, Prog. Nucl. Acid Res. Mol. Biol. 61 (1998) 181-209.

[56] M. Pimkin, G.D. Markham, The CBS subdomain of inosine 5'-monophosphate dehydrogenase regulates purine nucleotide turnover, Mol. Microbiol. 68 (2008) 342-359.

[57] J. Kichina, A. Green, S. Rauth, Tumor suppressor p53 down-regulates tissuespecific expression of tyrosinase gene in human melanoma cell lines, Pigment Cell Res. 9 (1996) 85-91.

[58] K. Nylander, J.C. Bourdon, S.E. Bray, N.K. Gibbs, R. Kay, I. Hart, P.A. Hall, Transcriptional activation of tyrosinase and TRP-1 by p53 links UV irradiation to the protective tanning response, J. Pathol. 190 (2000) 39-46. 